\title{
Firuz Akhrorov (1937-2012) and his contributions to the study of Chironomidae in Tajikistan
}

\author{
Andrey PRZHIBORO, ${ }^{1 *}$ Abdusattor SAIDOV, ${ }^{2}$ Ninel PETROVA ${ }^{1}$ \\ ${ }^{1}$ Zoological Institute, Russian Academy of Sciences, 1 Universitetskaya Emb., St Petersburg 199034, Russia; ${ }^{2}$ Department of Biological \\ and Medical Sciences, Academy of Sciences of the Republic of Tajikistan, 33 Rudaki Av., Dushanbe 734025, Tajikistan \\ *Corresponding author: dipteran@mail.ru
}

The paper is dedicated to the memory of Firuz Akhrorov (1937-2012), noted Tajik hydrobiologist and chironomid researcher. The contributions of F. Akhrorov to chironomid research are reviewed briefly. A list of Akhrorov's published works on Chironomidae (35 titles) is provided, as is a list of taxa he described in Chironomidae (18 species names).

Key words: Firuz Akhrorov; Chironomidae; benthos; lakes; Tajikistan; Pamir.

Received: February 2018. Accepted: July 2018.

This paper was presented at the 20th International Symposium on Chironomidae, Trento, Italy, 2-8 July 2017.

Session: In Memoriam.

This small paper is dedicated to the memory of Firuz Akhrorov, Tajik hydrobiologist, who has significantly contributed to the knowledge of ecology and biodiversity of water bodies in Tajikistan, and especially to the research on aquatic Chironomidae in this poorly investigated region.

Firuz Akhrorovich Akhrorov was born on 20 February 1937 in the Gissar District of Tajikistan. In 1960, Firuz graduated from V.I. Lenin Tajik State University in Dushanbe (presently, Tajik National University), and was invited to the staff of the Institute of Zoology and Parasitology of the Academy of Sciences of Tajikistan. All subsequent scientific work by F. Akhrorov was connected with this institute. Later on, F. Akhrorov headed the Department of Ichthyology and Hydrobiology of the same institute for more than 30 years.

In the period from 1969 to 1977, Firuz Akhrorov described 18 new species of Chironomidae from Tajikistan and Uzbekistan (see the list of species below) and, at a later time, he published the first faunal reviews of the Chironomidae inhabiting water bodies in the Pamirs (Akhrorov, 1988, 2004; and references thereafter; see the list of his publications below). In fact, Akhrorov became the first qualified expert on the Chironomidae not only in Tajikistan but also in all the large region of Soviet Middle Asia. However, hydrobiology was the main area of his scientific work; first and foremost, Firuz investigated bottom communities of lakes and reservoirs, lake ecosystems, and the feeding of commercial fish species.

In 1970, Firuz Akhrorov defended his Ph.D. dissertation, entitled "Bottom fauna of Kairak-Kum Reservoir and its use by food fish". From the mid-1960s to

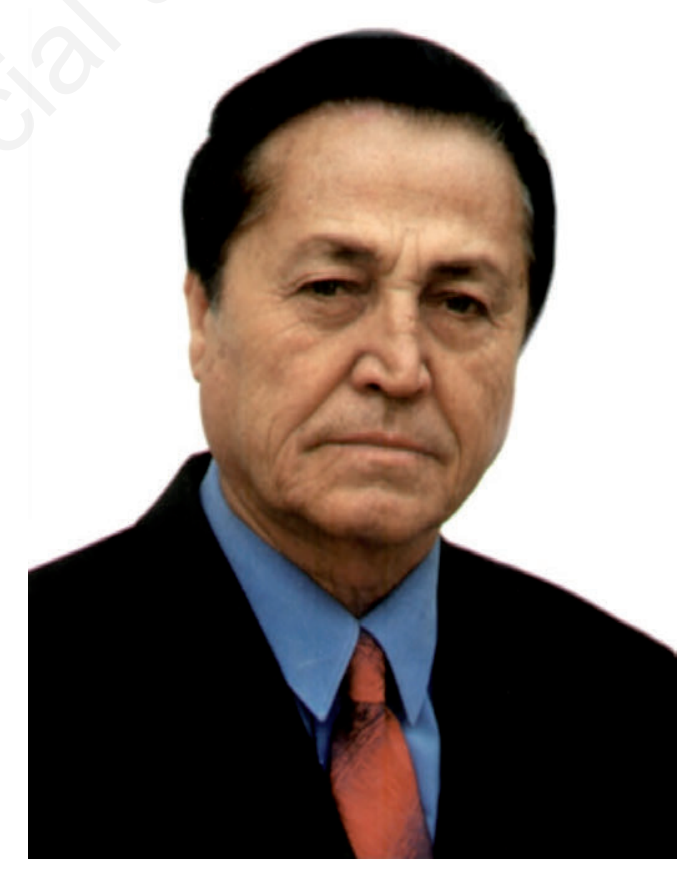

Firuz Akhrorov (2000s).

the 2000s, Akhrorov jointly with colleagues conducted indepth research on ecosystems and biodiversity of unique high-mountain (3700-4500 $\mathrm{m}$ above sea level) lakes in the Pamirs. Stationary field studies of several large lakes (Yashil-Kul, Bulun-Kul, Zor-Kul, Kara-Kul) was conducted during the entire warm season or even over several seasons, which enabled Akhrorov and his associates 
to collect rich and diverse material. In addition, they undertook expeditions to investigate many further Pamir lakes as well as other standing and running waters of Tajikistan (rivers, residual marshy water bodies, warm springs, etc.).

In the course of his research on aquatic ecosystems and their biodiversity, F. Akhrorov was the first in Tajikistan to investigate the taxonomic structure of chironomids in benthic communities of lakes and reservoirs and the habitat distribution of their immature stages, based on the large material. For several water bodies, he obtained the first detailed data on abundant chironomid species, i.e. studied their life histories, growth parameters of larvae and the respective duration of their development. Using the quantitative data on abundance and biomass, F. Akhrorov calculated production values for abundant chironomid species. In addition, he conducted studies on the feeding of commercial fish species in the same lakes, including evaluations of the corresponding importance of chironomids. Thereby, the large amount of quantitative data was used for the first assessments of the functional role of chironomids in the ecosystems of lakes and reservoirs of Tajikistan. Such a study of high-mountain lakes situated in extreme environments in distant areas can be considered as unique. The results of this work have been published most comprehensively by Firuz Akhrorov in a final monograph entitled "Aquatic fauna and biological productivity of high-mountain lakes of Pamir" (2006). In total, F. Akhrorov published the results of chironomid studies in lakes, reservoirs and running waters in more than 30 papers listed below (in many of these publications, chironomid larvae were considered as components of communities and ecosystems).

One more important but still underestimated contribution by Firuz Akhrorov to chironomid research is "A handbook on study of Chironomidae" (1982). In the 1960s to 1970s, several tens of graduated scientists and many young students participated in chironomid research at many scientific institutes and universities of the Soviet Union. However, until the 1980s there was no manual or tutorial in Russian on the methods and techniques in chironomid research. The late V.Ya. Pankratova and other chironomid researchers were discussing an idea to write such a book within the Zoological Institute of Soviet Academy of Sciences (in Leningrad, now St Petersburg) at the time when they met Firuz Akhrorov, who came to the Zoological Institute on a business trip. Firuz took the initiative to edit and organize the publication of this book, which was not an easy task at that time, and proved himself as an excellent organizer. He invited the leading Soviet chironomid researchers, V.Ya. Pankratova, N.Yu. Sokolova, A.I. Shilova, N.I. Zelentsov, L.A. Chubareva and N.B. Il'inskaya, to participate in writing the

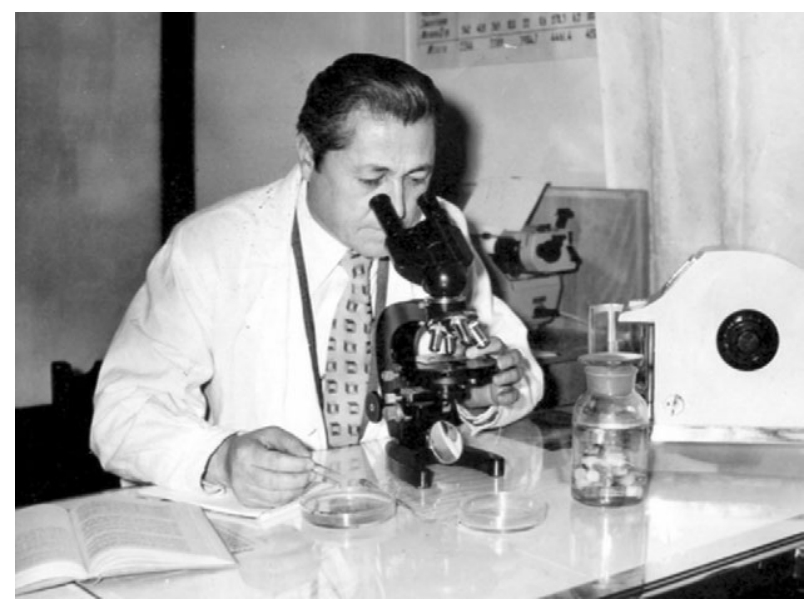

Firuz Akhrorov at his work place in the Institute of Zoology and Parasitology in Dushanbe (1980s?).

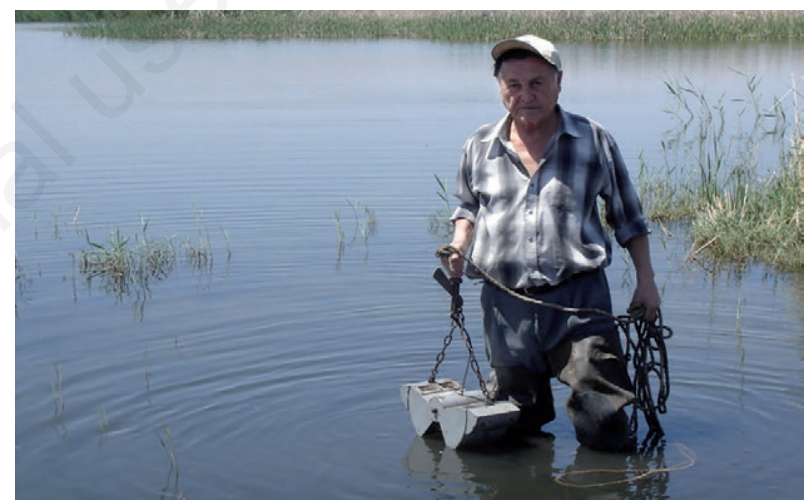

Firuz Akhrorov during field work at a lake in "Tigrovaya Balka" Nature Reserve, SW Tajikistan (2008?).

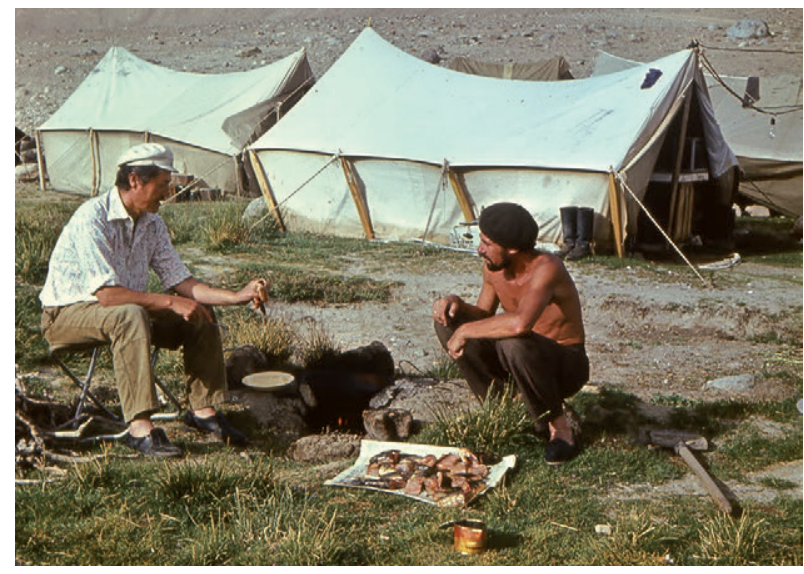

Firuz Akhrorov (left) and Nikolai Zelentsov (right) during an expedition to high-mountain lakes of the Pamirs (late 1970s early 1980s). 
handbook, and all of them prepared the chapters on different methods in chironomid research. A small book published in Dushanbe in 1982 became the first and so far only 'Chironomidae handbook' in Russian; many students who start to study Chironomidae still actively use this book.

Firuz Akhrorov passed away on 2 March 2012. In the memories of colleagues - chironomid researchers and aquatic ecologists - Firuz will remain as a modest and kind person, who loved the nature of Tajikistan and his work, and at the same time as an excellent, many-sided researcher and organizer of science, who has left behind a rich scientific heritage.

\section{PUBLICATIONS OF F. AKHROROV}

The list is arranged in chronological order and includes only the publications with species-group names of Chironomidae mentioned in the text. These works were written in Russian, unless indicated otherwise below. Titles of papers are given as English translations, book titles as transliterations followed by translations [in brackets]. The journal title "Izvestiya Akademii Nauk Tadzhikskoi SSR, Otdelenie biologicheskikh nauk" is abbreviated as "Izv. AN Tadzh. SSR"; "Izvestiya Akademii Nauk Respubliki Tajikistan, Otdelenie biologicheskikh i meditsinskikh nauk" as "Izv. AN Tajikistan".

Akhrorov F, 1967. Some data on the bottom fauna in Pamir lakes (Yashil-Kul and Bulun-Kul). Izv. AN Tadzh. SSR 1967[= overall No. 27]:64-73.

Akhrorov F, 1968[as “1967”]. New species of chironomids (Diptera, Chironomidae) from lakes Yashil-Kul and Bulun-Kul (Pamir). Dokl. Akad. Nauk Tadzhikskoi SSR 10:68-70. [See Ashe and O'Connor (2012: 807) for the date of publication].

Akhrorov F, 1968. New forms of larvae of the genus Stictochironotus[sic!] (Diptera, Chironomidae) from water bodies of Tajikistan. Dokl. Akad. Nauk Tadzhikskoi SSR 11:70-72.

Akhrorov F, 1968. Materials on feeding of some fish species in Kairak-Kum Reservoir. Izv. AN Tadzh. SSR 1968 [= overall No. 31]:104-109.

Akhrorov F, 1969. Peculiarities of species composition and quantitative development of bottom fauna in Kairak-Kum Reservoir (based on the material of 1963-1966). Izv. AN Tadzh. SSR 1969[= overall No. 36]:42-54.

Akhrorov F, 1970. Donnaya fauna Kairak-Kumskogo vodokhranilishcha i ee ispol'zovanie promyslovymi rybami [Bottom fauna of Kairak-Kum Reservoir and its use by food fish]. Abstract of Candidate of biological sciences dissertation. Tashkent: $21 \mathrm{pp}$.
Akhrorov FA, 1972. Materials on hydrobiology of Kattasai Reservoir (environs of Ura-Tepa town; northern Tajikistan), p. 46-47. In: Konferentsiya "Biologicheskie osnovy rybnogo khozyaistva respublik Srednei Azii i Tadzhikistana" [Conference "Biological basics of fish industry in republics of Middle Asia and Tajikistan"], Fergana, 25-29 Sept. 1972. Abstracts. Tashkent \& Fergana.

Akhrorov FA, 1973. Communities of Kairak-Kum Reservoir, p. 173-174. In: Vodoemy Sibiri i perspektivy ikh rybokhozyaistvennogo ispol'zovaniya [Water bodies of Siberia and perspectives of their use in fish industry]. Materials of regional conference for studying of waters in Siberia. Tomsk University Press.

Akhrorov F, 1974. Materials on the study of macrozoobenthos in lakes of the floodplain of the Vakhsh River. Izv. AN Tadzh. SSR 1974[= overall No. 54]:54-58.

Akhrorov F, 1974. Materials on the study of mass forms of chironomid larvae from the Kairakkum Reservoir. Izv. AN Tadzh. SSR 1974[= overall No. 55]:73-78.

Akhrorov F, 1975. New forms of chironomid (Diptera, Chironomidae) larvae from the Kairak-Kum Reservoir. Gidrobiol. Zh. 11:66-71. [English translation: Hydrobiol. J. 11:49-52].

Akhrorov F, 1975. Summary of hydrobiological studies in Tajikistan for 50 years, p. 43-61. Materials on hydrofauna of water bodies in the flooded area of Nurek Reservoir and some problems of formation and enrichment of its food basis, p. 140-141. In: M.N. Narzikulov (ed.), Zoologicheskii sbornik [Collected papers in zoology], 1. Donish, Dushanbe.

Akhrorov F, Ergashboev I, 1975. Materials on zoobenthos of some small water bodies in environs of Lake ZorKul. Communication 2. Izv. AN Tadzh. SSR 1975[= overall No. 61]: 36-42.

Akhrorov F, 1976. Materials on the formation of macrozoobenthos of Nurek Reservoir, p. 41-43. In: Biologicheskie osnovy rybnogo khozyaistva respublik Srednei Azii i Kazakhstana [Biological basics of fish industry in republics of Middle Asia and Kazakhstan]. Materials of the 15th scientific conference, 6 Oct. 1976. Donish, Dushanbe.

Akhrorov F, 1977. New species of the genus Psectrocladius (Diptera, Chironomidae) from Pamir and their metamorphosis. Zool. Zh. 56:538-549.

Akhrorov F, Kondur LV, 1981. Food for game fish in Pamir lakes. Izv. AN Tadzh. SSR 1981[= overall No. 82]:48-53.

Zelentsov NI, Akhrorov F, 1981. Pamir chironomids of the genus Psectrocladius Kieff. (Diptera, Chironomidae, Orthocladiinae). Izv. AN Tadzh. SSR 1981[= overall No. 84]:71-74.

Akhrorov F, Andrievskaya SA, Grishchenko EV, 1981. 
On biological productivity of Lake Yashilkul in Pamir, p. 84-85. In: IV s'ezd Vsesoyuznogo gidrobiologicheskogo obshchestva [4th congress of All-Union hydrobiological society], Kiev, 1-4 Dec. 1981. Abstracts, 4. Naukova Dumka, Kiev.

Akhrorov FA, 1982. Zoobenthos, p. 137-180. Supplement. Composition of flora and fauna of Kairak-Kum Reservoir, p. 283-285. In: M.N. Narzikulov (ed.), Kairakkumskoe vodokhranilishche: rezul'taty issledovanii po gidrobiologii [Kairak-Kum Reservoir: results of research in hydrobiology]. Donish, Dushanbe. [Species list of Chironomidae: $p$. 283-285].

Akhrorov F (ed.), 1982. Metodicheskoe posobie po izucheniyu khironomid [A handbook on study of Chironomidae]. Donish, Dushanbe: 84 pp.

Akhrorov F, 1983. Hydrological and hydrobiological characteristics of the lake system Chakankul in Pamir, p. 51-52. In: Biologicheskie osnovy rybnogo khozyaistva vodoemov Srednei Azii i Kazakhstana [Biological basics of fish industry in water bodies of Middle Asia and Kazakhstan]. Abstracts. Materials of 18th scientific conference, Tashkent, 27-29 Sept. 1983. Fan Publ. of Uzbek SSR, Tashkent.

Akhrorov FA, 1984. Chironomid larvae in water bodies of Pamir, p. 11-12. In: Limnologiya gornykh vodoemov [Limnology of mountain water bodies]. Abstracts of All-Union Conference on limnology of mountain water bodies, Sevan, 11-15 Sept. 1984; Yerevan.

Akhrorov F, 1985. Benthos of Lake Yashchilkul and its production. Gidrobiol. Zh. 21:16-23.

Akhrorov F, Alibaeva MM, 1985. Bottom fauna of water bodies, p. 194-198. In: M.N. Narzikulov (ed.), Zoologicheskaya nauka Tadzhikistana za 60 let [Zoological science of Tajikistan for 60 years]. Donish, Dushanbe.

Akhrorov F, 1988. Fauna of Chironomidae of Pamir water bodies. Izv. AN Tadzh. SSR 1988[ $=$ overall No. 113]:38-42.

Akhrorov F, 1990. Materials on hydrofauna of water bodies in the flooded area of Bal'dzhuan Reservoir and some problems of formation of its biological regime. Izv. AN Tadzh. SSR 1990[= overall No. 119]:20-26.

Akhrorov F, 1997. Productivity of benthic fauna in some ponds of Kuibyshev fish farming in southern Tajikistan. Izv. AN Tajikistan, 1997[= overall No. 136]:52-58.

Akhrorov F, 1999. Benthos of Lake Karakul (Pamir) and its productivity. Selevinia 1998-1999:79-82.

Akhrorov F, 1999. Species composition of aquatic fauna of Lake Zorkul (Pamir). Selevinia 1998-1999:232-234.

Akhrorov F, Alibaeva MM, 1999. Materials on aquatic fauna of Lake Zorkul (Pamir). Dokl. Akad. Nauk Respubliki Tajikistan 42:38-43.

Akhrorov F, 2001. Communities of Lake Zorkul. Izv. AN Tajikistan 2001[= overall No. 142]:87-96.

Akhrorov F, 2001. Donnaya fauna vodoemov Pamira (biologiya, ekologiya, produktsiya i genesis) [Bottom fauna of water bodies of Pamir]. Ph.D. in Biological Sciences Dissertation. Dushanbe: 48 pp.

Akhrorov F, Konunov E, 2004. Biological resources of lakes of Pamir, p. 158-162. In: Fauna i ekologiya zhivotnykh Tadzhikistana [Fauna and ecology of animals of Tajikistan]. Materials of scientific conference dedicated to the 90th anniversary of Academician of Tajikistan Academy of Sciences M.N. Narzikulov, Dushanbe, 13-14 June 2004.

Akhrorov F, Alibaeva M, 2004. Chironomids in water bodies of Pamir and their habitat distribution, p. 176180. In: See preceding title.

Akhrorov F, 2006. Gidrofauna i bioproduktivnost' vysokogornykh ozer Pamira [Aquatic fauna and biological productivity of high-mountain lakes of Pamir]. Trudy Instituta Zoologii i Parazitologii im. E.I. Pavlovskogo, 1(27): 285 pp. [incl. Chapter 8: Biology of abundant species of chironomids (larvae) and crustaceans in lakes of Pamir, p. 163-198].

\section{LIST OF TAXA DESCRIBED BY F. AKHROROV IN CHIRONOMIDAE}

In several of Akhrorov's published proposals of new taxa, he presented the respective new species name in a form such as, e.g., "Diamesa 1. samarkandica sp. n." (Akhrorov, 1975:67). In each of these presentations, the term "1." (or "L.") reflected that the life stage described was the larva. These interjected terms are considered as not precluding nomenclatural availability of the corresponding names (e.g., Ashe and O'Connor, 2012).

Diamesinae:

Diamesa samarkandica Akhrorov, 1975 (originally D. "l. samarkandica"; nomen dubium: Ashe and O'Connor, 2009).

Orthocladiinae:

Eukiefferiella ozhegovae Akhrorov, 1968 (originally E. "1. ozhegovae"; nomen dubium: Ashe and O'Connor, 2012).

Psectrocladius acatovae Akhrorov, 1977 (junior synonym of P. litofilus Akhrorov, 1977: Zelentsov, 1980; Ashe and O'Connor, 2012).

Psectrocladius dispar Akhrorov, 1977 (junior synonym of P. barbimanus (Edwards, 1929): Zelentsov, 1980; Ashe and O'Connor, 2012).

Psectrocladius litofilus Akhrorov, 1977. 
Psectrocladius pseudostilatus Akhrorov, 1975 (originally Ps. "l. pseudostilatus").

Psectrocladius goetghebueri Akhrorov, 1977 (junior synonym of $P$. barbimanus (Edwards, 1929): Zelentsov, 1980; Ashe and O'Connor, 2012).

Psectrocladius nevalis Akhrorov, 1977.

Psectrocladius pamiricus Akhrorov, 1977 (originally PS. "pamirica"; junior synonym of $P$. barbimanus (Edwards, 1929): Zelentsov, 1980; Ashe and O'Connor, 2012).

Psectrocladius pancratovae Akhrorov, 1977.

Psectrocladius symbioticus Akhrorov, 1977 (originally Ps. "symbiotica"; junior synonym of $P$. barbimanus (Edwards, 1929): Zelentsov, 1980; Ashe and O'Connor, 2012).

Psectrocladius tadshikistanicus Akhrorov, 1977 (junior synonym of $P$. pancratovae Akhrorov, 1977: Zelentsov, 1980; but instead considered as junior synonym of $P$. barbimanus (Edwards, 1929): Ashe and O'Connor, 2012).

Psectrocladius zernovi Akhrorov, 1977 (junior synonym of P. barbimanus (Edwards, 1929): Zelentsov, 1980; Ashe and O'Connor, 2012).

Pseudosmittia rivulorum Akhrorov, 1975 (originally Ps. "l. rivulorum"; nomen dubium: Ashe and O’Connor, 2012).

Chironominae:

Cryptochironomus kasimovi Akhrorov, 1975 (originally Cr. "l. kasimovi"; nomen dubium, "probably" Acalcarella kasimovi (Akhrorov, 1975): Ashe and Cranston, 1990).

Stictochironomus narzykulovi Akhrorov, 1968 (originally St. "L. narzykulovi"; nomen dubium: Ashe and Cranston, 1990).
Stictochironomus tadzikistanicus Akhrorov, 1968 (originally St. "L. tadzikistanica"; nomen dubium: Ashe and Cranston, 1990).

Tanytarsus longipes Akhrorov, 1968 (originally T. "l. longipes"; nomen dubium: Ashe and Cranston, 1990).

\section{ACKNOWLEDGEMENTS}

The authors are grateful to Martin Spies for careful reviewing the MS and numerous useful corrections. This study was performed in the frame of the State Research Programme No. AAAA-A17-117021310121-0 of Russian Federation.

\section{REFERENCES}

Ashe P, Cranston PS, 1990. Family Chironomidae, p. 113-355. In: Á. Soós and L. Papp (eds.). Catalogue of Palaearctic Diptera. 2. Psychodidae - Chironomidae. Akadémiai Kiadó, Budapest.

Ashe P, O'Connor JP, 2009. A world catalogue of Chironomidae (Diptera). Part 1. Buchonomyiinae, Chilenomyiinae, Podonominae, Aphroteniinae, Tanypodinae, Usambaromyiinae, Diamesinae, Prodiamesinae and Telmatogetoninae. The Irish Biogeographical Society, Dublin: 445 pp.

Ashe P, O'Connor JP, 2012. A world catalogue of Chironomidae (Diptera). Part 2. Orthocladiinae. Irish Biogeographical Society, Dublin: published in two volumes (Sections A, B), [14]: 468 pp.; [6]: 500 pp.

Zelentsov NI, 1980. [Revision of the Pamirian Orthocladiinae of the genus Psectrocladius Kieff. (Diptera, Chironomidae)]. [Article in Russian]. In: Morfologiya i biologiya presnovodnykh bespozvonochnykh [Morphology and biology of freshwater invertebrates]. Trudy Instituta Biologii Vnutrennikh Vod AN SSSR 44:110-135. 